DOI https://doi.org/10.18551/rjoas.2018-05.21

\title{
SCENARIO PLANNING TO INCREASE THE VALUE OF LOCAL AGRIBUSINESS COMMODITIES IN INDRAGIRI HILIR DISTRICT OF RIAU
}

\author{
Bustamin*, Muluk M.R. Khairul, Hermawan \\ Magister of Public Administration, Faculty of Administrative Sciences, \\ University of Brawijaya, Malang, Indonesia \\ *E-mail: Bustamin16ub@gmail.com
}

\begin{abstract}
Indragiri Hilir District as the largest producer of coconut commodity on National and International scale has not been able to provide prosperity for the society whose $70 \%$ of economy depends on the sector. This is due to high complexity of existing problems. Therefore, this research used scenario planning concept with SRI method because the approach is able to accommodate the complexity and high uncertainty and is suitable for future decision-making. Data was collected through interview, observation, and secondary data to determine six stages of SRI, namely strategic decision, key decision factors and environmental forces by using macro analysis (SEPT) and micro (Five Forces Porter), the outputs later become inputs for making scenario logic, then described in details on strategy implications. This paper offers 4 alternative scenarios to increase the value of future coconut commodity Inhil Scintillating and Inhil Industry Growth as scenario optimization. While Inhil Challenging as a moderate scenario, Inhil Dreaming becomes the worst scenario for the sustainability of coconut industry in Inhil District.
\end{abstract}

\section{KEY WORDS}

Coconut, commodity, scenario, planning, SRI method.

The role of potential local resources in the era of regional autonomy development has a high urgency since it can be self-supporting for the region. Economic growth supported by regional superior commodities can be used as a tool for development of people in the region (Oktavia et al., 2016). One of sectors that has always become government's attention is agricultural / plantation sector, for its role in massive economic development (Dewi \& Santoso, 2014).

The agricultural / plantation sector has become a matter of choice for a concurrently managed government based on principles of accountability, efficiency, and externalities, as well as national strategic interests. (Law Number 23 Year 2014). This is because the sector contributes greatly to the economy of society (Chalid, 2009; Oktavia et al., 2016). Hopewell (2014) conducted a study on agribusiness in Brazil, the Brazilian Government has made a development policy on the export-based agribusiness sector during the past two decades. The results show that Brazil was proved to be able to improve the economy of its people through the agribusiness sector. A similar study conducted by Haggblade (2011) under the title of"Modernizing African Agribusiness: Refflections for the Future"reported that in the last 30 years, agribusiness sector of Africa was managed to improve the economy of community through the concept of upstream and downstream industry management.

The majority of the world's population earns their livelihood from the agricultural/ plantation sector (Mardikanto \& Soebiato, 2017: 55), likewise Indonesia as an agrarian country, where the majority of the population still relies on agricultural / plantation sector as the economic support. One of them is Inhil District where the contribution of GRDP is dominated by this sector, especially coconut commodity (Cocos nucifera). This condition is supported by the largest coconut production of Inhil District nationwide and worldwide by contributing about $82.15 \%$ to $13.14 \%$ national production (Outlook of coconut commodity, 2014).

Interestingly, the majority of ownership of coconut plantations in Inhil Districtis under local community. This is supported by data suggesting that $70 \%$ of community economy 
depends on the sector. Therefore, the region's superior commodities (coconut) are expected to improve community economy through such agricultural/ plantation sector. However, this condition is still far from expectations. This is because there are various problems in coconut commodities that occur in Inhil District, including: (1) oligopsonyof coconut market so that the price of coconut is cheap, even more at farmer's level; (2) price fluctuations; (3) about 100,000 hectares of plantations damaged by a faulty ofthree-water system, (4) a large number of old coconut plantations and pest-attacked coconut plantations. However, the most crucial issues area low coconut price and uncontrolled price fluctuations.

Considering these conditions, the Inhil District Government has several development policies/ programs to overcome such existing problems, including (1) the threewater system program; (2) the coconut rejuvenation; (3) the promotion of potential regional excellence; (4) the implementation of Warehouse Receipt System (SRG); (5) the establishment of Regional Owned Enterprises (BUMD); and (6) the formation of Local Regulation Draft (Ranperda) of Coconut Trading System. However, among the policies/ programs mentioned, only a few that are possibly implemented i.e. points 1,2 and 3, even not optimally. Others are still in the planning process. This is due tothe low commitment of Local Government, the dragging of good interests either from governments (Local Government and Regional Representative Council (DPRD) of Inhil District) and especially the interests of private parties (PT. Sambu Group, PT. Kokonako and PT. Inhil Sarimas).

Therefore, Inhil District Government is required to make acceleration in regional development planning to overcome the occurring conditions. This is because development basically aims to improve human welfare in the broad senses (Kartasasmita, in Mardikanto \& Soebiato, 2017: 9). However, regional development planning is a development planning process intended to create a change towards a better development for community, government, and its environment in a certain region, by utilizing various existing resources. Itmust have an orientation that is comprehensive, complete, but still adhering to the principle of priority (Riyadi and Bratakusumah, 2004: 7).

Therefore, this study aims to formulate scenario that improves the value of coconut agribusiness commodity in Inhil District,in spite ofthehigh complexity occurring. This study used scenario planning approach as "Tools of Analysis" since the approach is able to provide some effective alternatives, despite high uncertainties existing. Lindgren \& Bandhold's (2003) suggested that the use of scenario planning is based on high uncertainty. Scenario planning is one approach or tool for conveying perceptions about future environmental alternatives for an appropriate decision (Peter Schwartz, 1991 quoted by Lindgren \& Bandhold, 2003: 21). Scenarios are considered as a tool to better understand the strategic implications of uncertainty because they are consistent insight into what will happen in the future (Porter, 1994: 444).

Scenario planning has many methods however, this study, used the Standford Researh Institute (SRI) method for its relevance to this study. In addition, SRI's approach has experienced to create scenarios to serve as a basis for decision-making and strategy (Ringland, 1998: 194).

\section{METHODS OF RESEARCH}

Scenario planning research is a study that uses a qualitative approach. Data analysis was conducted by utilizing SRI scenario method with 6 (six) steps, namely: strategic decision, key decision factors, environmental forces, scenario logic, scenario, and strategy implications. (Ringland, 1998). Analysis must comply with the rules of each stage. Firstly, in strategic decisions, as the name suggests, to make strategic decisions in increasing the value of local agribusiness commodities (coconut) in the future were determined by selectinga period of 25 years ahead. However, determining these strategic decisions should be based on the second step. Secondly, all key decision factors (main trend) were determined in the step of key decision factors (Ringland, 1998 \& Kroneberg, 2000).

Next,the third step called external forces; is when external power analysis was done by looking at micro and macro conditions. Micro scale was analyzed using Porter's competitive 
forces analysis which includes competitors, suppliers, customers, substitutes and potential entrants (Porter, 1994). Meanwhile, for the macro scale, SEPT (Social, Economic, Political and Technological) was used. After that, the fourth step called scenario logic is conducted to group (low, medium, and high) uncertainties that have been identified in the previous step. Then, to reduce the number of uncertainties identified, an analysis method of causal-loop diagram was carried out to finally present 4 (four) scenarios of increasing the value of coconut commodity. Whereas, the fifth step scenario was done to describe or make a detailed description of the 4 scenarios that have been made in the previous step. Subsequently, decision implications are the last step, in which an implication analysis of each scenario (positive/ negative) on the strategic decision that has been set previously was conducted.

\section{RESULTS AND DISCUSSION}

The research found the fact that coconut plantations in Inhil District are approximately 429,694 hectares in width. However, a massive damage occurring in 100,254-hectare plantations as a result of a faulty in the water system (construction of embankment, normalization of ditch/ canal, and construction of gate valve) causes a decrease in the production of crops. Moreover, old coconut plantations and pest (beetle, pig, and monkey)attacked coconut plantations were also noticed. As a matter of fact, the low and fluctuating prices of coconut in past decades has led people to not look after their plantations since the working costs and production throw them off-balance (lost). Accordingly, a drop in production of coconut in Inhil District occurs. In line with a study conducted by Muhi (2011), the seasonal condition of agricultural/ plantation sector productions and a phenomenon of the falling price of agricultural commodities (particularly during great harvest) have been latent problems which incredibly harm farmers. Furthermore, some of them are often unwilling to harvest their crops due to a higher cost spent on harvesting than what they could sell.

The research found the fact that coconut plantations in Inhil District are approximately 429,694 hectares in width. However, a massive damage occurring in 100,254-hectare plantations as a result of a faulty in the water system (construction of embankment, normalization of ditch/ canal, and construction of gate valve) causes a decrease in the production of crops. Moreover, old coconut plantations and pest (beetle, pig, and monkey)attacked coconut plantations were also noticed. As a matter of fact, the low and fluctuating prices of coconut in past decades has led people to not look after their plantations since the working costs and production throw them off-balance (lost). Accordingly, a drop in production of coconut in Inhil District occurs. In line with a study conducted by Muhi (2011), the seasonal condition of agricultural/ plantation sector productions and a phenomenon of the falling price of agricultural commodities (particularly during great harvest) have been latent problems which incredibly harm farmers. Furthermore, some of them are often unwilling to harvest their crops due to a higher cost spent on harvesting than what they could sell.

The pricing issue in coconut plantation sector in Inhil District is indeed crucial since price is a determinant of success in trading. Moreover, people have not been able to process coconut-derived products (stem, leaf, fiber, shell, etc.) to add their economic value, rather still fixated on coconut flesh. Based on analysis of scenario planning using SRI method in order to improve the value of coconut commodity in Inhil District, there are 6 steps suggested as follows.

First Step: Strategic Decisions. The first step in the SRI scenario method is carrying out identification and description in details of the desired goals, as Mandel (1993) in Kroneberg (2007: 75) suggested. Therefore, we performed in-depth interviews with key informants, including Regent (as a policy maker) and related stakeholders, i.e. Development Planning Agency at Sub-National Level (Bappeda), Department of Trade and Industry (Disperindag), Department of Plantations (Disbun), Head of Commission II of Regional Representative Council (DRPD) of Inhil District, and community leaders to observe strategic decisions for coconut commodity in Inhil District. It was concluded from the interviews that all the related 
stakeholders from regional government (executives), DPRD (legislatives), and community agree to formulate a strategy to improve the value of coconut commodity in Inhil District.

Second Step: Key Decision Factors. The second step is in which identification and review on which decisions that make up key decision factors to improve the value of coconut commodity in Inhil District were conducted. This step conforms to Ringland (1998:248) who questioned "what management would like to know about the future to make a better decision" and other experts, such as Mandel and Wilson (1993) in Kroneberg (2000:76) suggesting that "key decision factors are defined as the matters that decision-makers want more informasion about, in order to make a good strategic decision".

To discover the key decision factors, identification and analysis based on 4 (four) approaches were carried out, i.e. (1) interview with informants, (2) review on legalproduct,(3) review on planning document, and (4) observation. According to data (primary and secondary) analysis, it was concluded that to date, there are strategies set by Regional Government of Inhil District to improve the value of coconut commodity in the region, including (1) the three water system program, (2) the coconut rejuvenation program, (3) the promotion of regional potentials, (4) the implementation of Warehouse Receipt System (SRG), (5) the establishment of regional-owned enterprise (BUMD) of Inhil District, and (6) Regional Regulation Draft of Coconut Trading System. In addition, formation of cooperatives at every village, formation of soft financial institutions, as well as opening investment opportunities for domestic and foreign investors become concerns of the regional government, as decision factors are aimed to facilitate identifying external and internal forces (environmental conditions) (Kroneberg 2000:76).

Third Step: Environmental Forces. Analysis on external environment conditions was carried out in this step, under the pretext that internal factors are those controlled by the organization, while external factors are those not controlled by the organization (Pfeffer \& Salancik (1978) in Bryson, 2007: 62). By focusing on two categories, i.e. micro and macro forces (Ringland, 1998: 249-250), results from identification of key decision factors become a consideration in performing analysis on environmental forces, in which micro forces are analyzed based on Porte's five competitive forces, which include competitors, suppliers, customers, substitutes, and potential entrants (Porter's, 1980) through an emphasis on industries and markets (Ringland, 1998). Macro forces are analyzed using Social, Economic, Politic, and Technological (SEPT) approaches (Ringland, 1998 \& Bryson, 2007). According to the analysis on environmental forces, each trend, both macro and micro, in the improvement of coconut commodity value was found and presented in Figure 2.

Fourth Step: Scenario logic. Based on the analysis on environmental forces, uncertainties to improve the value of coconut commodity in Inhil District have been largely identified.

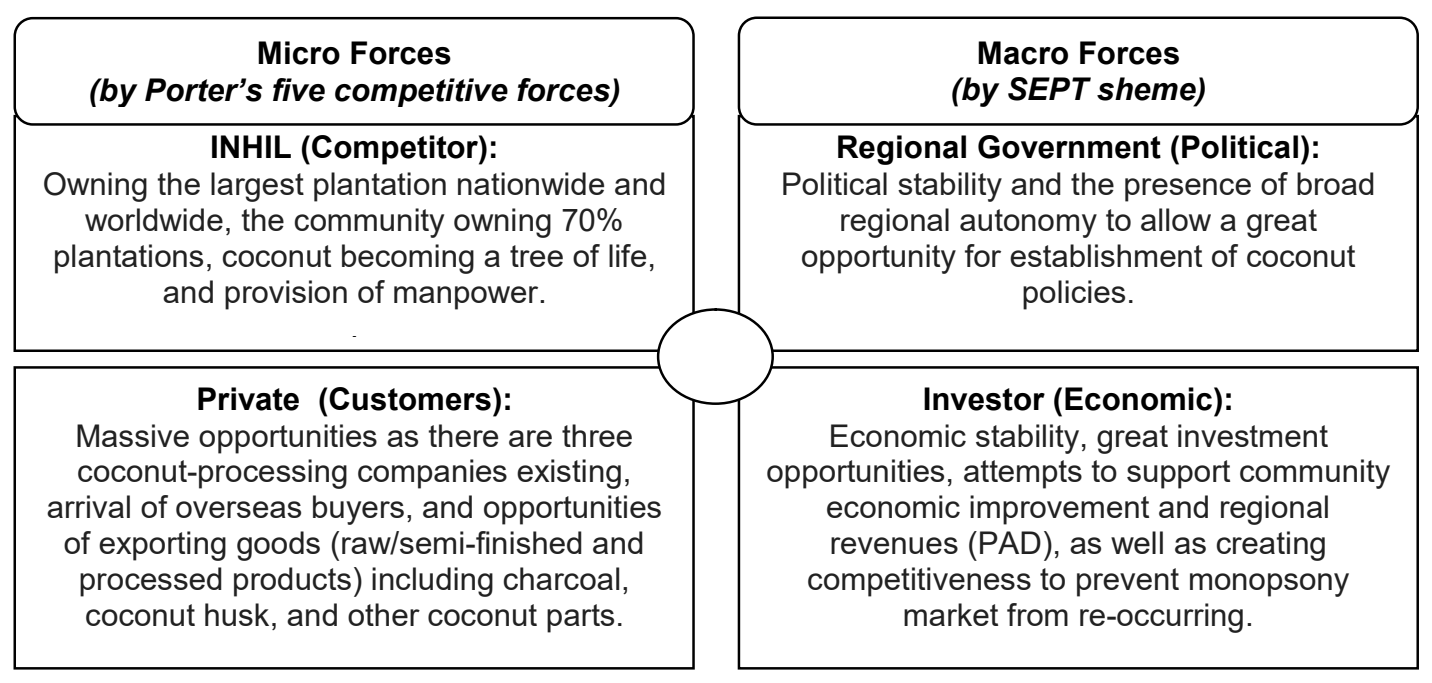

Figure 2 - Identification Results of External Factors (Source: Processed Data, 2018) 
As suggested by Korneberg (2000), grouping of uncertainties according to their levels into impact/uncertainty matrices was done, so that high impact uncertainties which comprise of political stability, oligopsony local markets, regulation changes, and conditions of coconut product demand were found. Medium level uncertainty comprises of plantation damage, overseas buyers, fluctuating prices, and land over-function. The purpose of uncertainty matrices according to Porter (1994) is that free uncertainty is an appropriate foundation to construct a scenario as it is the true source of uncertainty. Nevertheless low uncertainties are considered after making assumptions for each free uncertainty, and therefore they are a part of each scenario. Consequently, a technique of causal loop diagram is employed to eliminate the low uncertainties. Based on the analysis of causal loop diagram, scenario alternatives to improve the value of coconut agribusiness commodity in Inhil District are presented in Figure 3. Conforming to Ogilvy (2002), a scenario does not determine one vision/goal, except for proposing some future alternatives.

\section{Fifth Step: Scenarios}

This stage is in which depicting or describing in details the 4 (four) scenarios that have been made previously are done, in addition to rationalizing how each scenario is run. Then,goals and strategies are determined in each scenario because strategy is a tool to achieve goals (Rangkuti, 2008: 3). Strategy is a tool to achieve corporate/ public goals, in relation to longterm goals, follow-up programs, and resource allocation priorities (Chandler, 1962 in Rangkuti, 2008: 3).

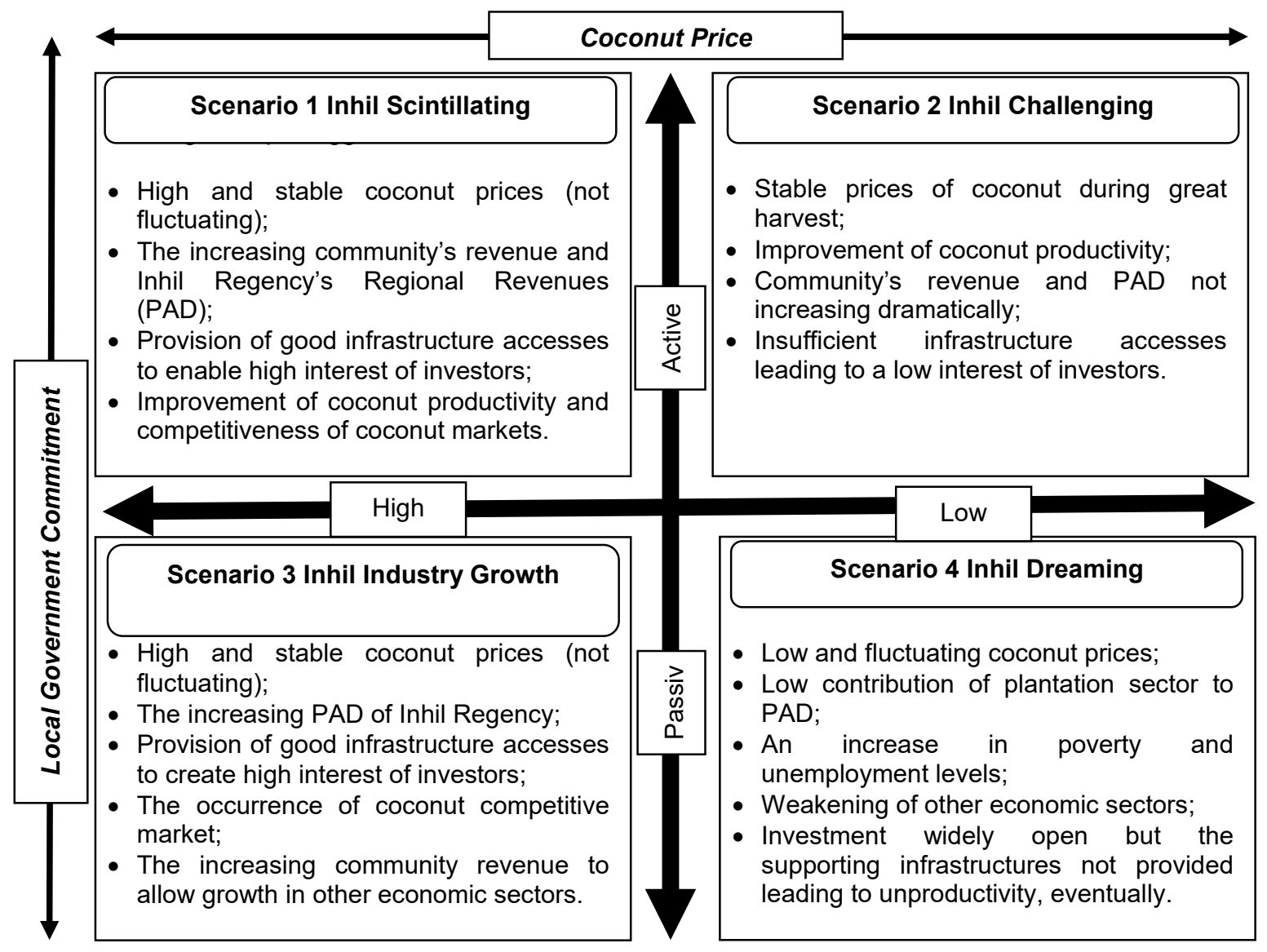

Figure 3 - Scenario logic of Improvement in The value of Coconut Commodity (Source: Processed Data, 2018)

Scenario 1 Inhil Scintillating (High coconut commodity price, Active Local Government) is a long-term planning with a period of 1-25 years in the future for its suitability to long-term planning (Lindgren \& Bandhold (2009), Ringland (2002) Porter (1994). Thus, to establish this scenario, the following stages are defined: (1) establishment of BUMDs managing upstream 
and downstream industries (2) establishment of cooperatives in each village and provision of supporting facilities, (3) development of transportation access (land and sea) including port and telecommunication, innovation of investment service, and strengthening regional potential promotion, (4) strengthening regulations to support coconut agribusiness, and (5) improvement of program of threewater system and coconut rejuvenation.

Scenario 2 Inhil Challenging comprises of Low coconut commodity price and Active Local Government. Scenario 2 is a scenario for a mid-term period of 1-10 years ahead as Lindgren \& Bandhold's (2009) suggested that scenario planning is also suitable to mediumterm planning. Thus, to achieve this scenario, strategies requiredare: (1) the establishment of BUMD as a provider of copra warehouse receipt

system (SRG) and the formation of cooperatives in each village and the provision of supporting facilities; (2) development of transportation access (land and sea), port, and telecommunication; (3) improvement of thethree water system and coconut rejuvenation program; (4) innovation of investment service and strengthening promotion of regional potentials; and (5) strengthening regulations to support coconut agribusiness.

Scenario 3 called Inhil Industry Growth is long-term planning (similar to the second scenario) but High coconut commodity price and Passive Local Government. Therefore, it has strategies through: (1) development of transportation access (land and sea), ports, and telecommunication as well as innovation of investment services; (2) strengthening the promotion of regional potentials; (3) increasing the amount of investment of the coconut industry; (4) enhancing high local community participation; (5) strengthening regulations to support coconut agribusiness.

Scenario 4 called Inhil Dreaming is the worst scenario (existing condition) due to its Low coconut commodity price and Passive Local Government, where Inhil District government only has strategies that are: (1) improvement of water system three program; (2) rejuvenation of coconut plantations (3) investment service and promotion of regional potentials; and (4) strengthening regulations to support coconut agribusiness.

Strategies in the above scenario are very important to achieve competitive advantage (porter, 1985), in increasing the value of coconut commodity in Inhil District. Hence, each scenario can be categorized as in Figure 4.

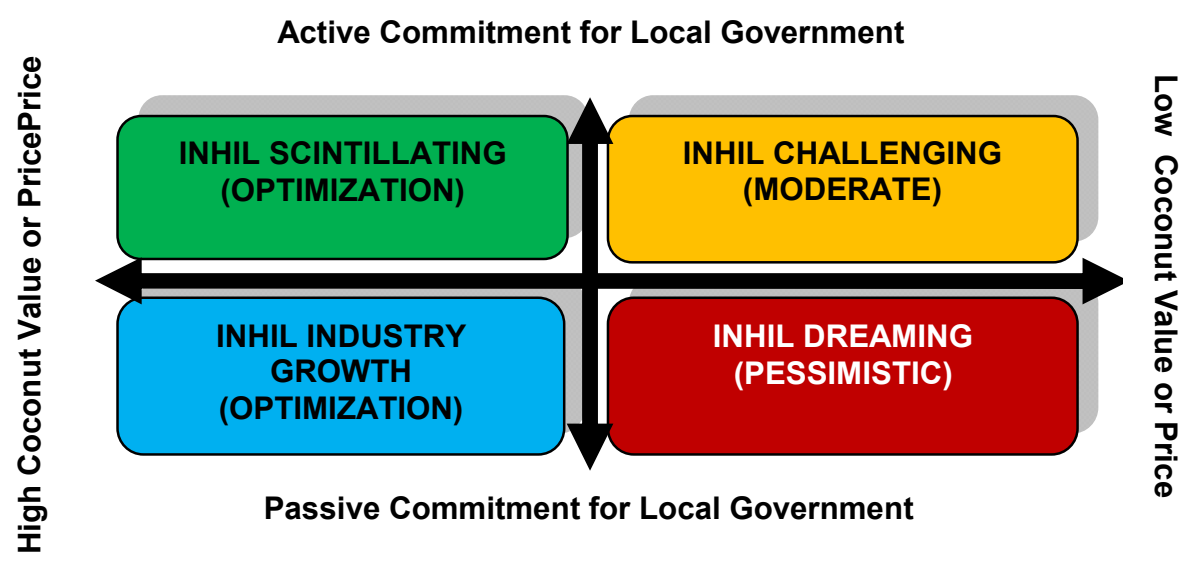

Figure 4 - Categorizing Future Scenarios

Sixth Step: Strategic Implication. The last step of the SRI scenario analysis is that participants describe scenarios in sufficient details to identify decision implications and to help develop and assess strategy options (in a form of risk-reward assessment) Ringland (1998). The four scenarios certainly have different implications for the future of coconut agribusiness in Inhil District. The scenario "Inhil Scintillating" is considered scenario optimization because it can create coconut agribusiness survival with an emphasis on establishment of BUMD that manage upstream and downstream sectors of coconut. However, it requires a high commitment from the government and a considerable cost to implement. Scenario of "Inhil Industry Growth" is also considered as scenario optimization 
because it is able to make coconut industry survive in the future by emphasizing on the concept of Local Economic Development (LED) through optimizing the utilization of local resources that involve government, businesses, local communities, and civil society organizations to develop economies in a region (Blakely, 1994 \& Adji, 2011 in Saragih, 2015). However, the government's role concentrates on accelerating the provision of supporting infrastructures for investment. Similarly said by Saragih (2015: 60), the role of local government is not limited to forming new business, but improving public services.

The "Inhil Challenging" scenario is considered a moderate scenario because if the scenario is implemented, there will be no significant change to coconut agribusiness in Inhil District. This is due to the emphasis on the implementation of SRG, whereas SRG has not been able to raise prices but keep the price fluctuating during great harvest and plummeted, eventually. Nevertheless, the commitment of Local Government is also profound for the provision of initial capital, Human Resources (SDM), and other supporting Infrastructure. Meanwhile, the scenario of "Inhil Dreaming" is classified into scenario "Pessimistic", meaning that if this condition continues to run, the future of coconut agribusiness in Inhil District will be getting worse.

\section{CONCLUSION}

The formulation of SRI scenario produced 4 alternative scenarios: Inhil Scintillating, Inhil Challenging, Inhil Industry Growth, and Inhil Dreaming. Scenarios 1 and 3, however, are scenario optimization for the future of coconut agribusiness, which is destined for long-term planning. Meanwhile, scenario 2 becomes an option for medium-term planning for its scenario moderate. However scenario 4 is the worst scenario for the future of coconut agribusiness in Inhil District.

\section{REFERENCES}

1. Central Bureau of Statistics Indragiri Hilir Regency. (2017). The Poverty Line and the Poor in Figures: BPS Inhil District.

2. Bryson, J. M. (2005). Strategic Planning for Social Organizations. Yogyakarta.

3. Chalid, N. (2009). The Role of Agricultural Sector in Riau Province. J. of Econ., 17(3).

4. Dewi, P.N.A. (2014). Development of Leading Commodity of Agricultural Sector of Food Crops in Karangasem District through Agribusiness Approach. Journal of Technique Pomits, 3(2).

5. Haggblade, S. (2011). Modernizing African Agribusiness: Reflections for the Future.1(1),

6. Hopewell, K. (2014). The Transformations in an Emerging Economy the Case of Brazilian Agribusiness. 10(4).

7. Kroneberg, A. (2000). Innovation in Shipping by Using Scenarios, DR. Ing (Unpublished Thesis). Dept. of Marine Design, Faculty of Marine Technology, University of Science and Technology, Norwegian.

8. Lindgrend, M., \& Bandhold, H. (2009). The link between future and strategy. New York.

9. Mardikanto, T. (2017). Community Empowerment in Perspective of Public Policy. Bandung.

10. Oktavia, F. H. (2016). The Role of Agricultural Sector in Economic Development in East Java Province (Input-Output Approach). Journal of Habitat, 27(2),

11. Ogilvy, A. J. (2002). Creating Better Futures, Scenario Planning as a Tool for a Better Tomorrow. New York: Oxford University Press, Inc.

12. Rangkuti, F. (2008). SWOT Analysis: Business Case Dissecting Technique. Jakarta.

13. Riyadi., \& Deddy, S. B. (2003). Regional Development Planning: A Strategy to Explain the Potential in Achieving Regional Autonomy. Jakarta: PT. Gramedia Pustaka Utama.

14. Ringland, G. (1998). Scenario planning: Managing for the future. New York: Wiley.

15. (2002). Scenarios in Public Policy. New York: John Wiley \& Sons LTD.

16. Republic of Indonesia, Law Number 23 Year 2014 on Regional Government. Jakarta.

17. Saragih, R. J. (2015). Regional Planning and Local Economic Development Based on Agriculture Theory \& Applications. Yogyakarta: Pustaka Pelajar. 